\title{
Effect of the decontamination using gamma irradiation on the essential oil of Turnera diffusa Wild.
}

\author{
Ely Eduardo Saranz Camargo, ${ }^{*, 1}$ Marcelo Telascrea, ${ }^{2}$ Wagner Vilegas ${ }^{2}$ \\ ${ }^{l}$ Faculdade de Ciências Farmacêuticas, Universidade Estadual Paulista Júlio de Mesquita Filho, Rodovia \\ Araraquara-Jaú, Km1, 14801-902 Araraquara-SP, Brazil, \\ ${ }^{2}$ Departamento de Química Orgânica, Instituto de Química, Universidade Estadual Paulista Júlio de Mesquita \\ Filho, Rua Francisco Degni, s/n, 14800-900 Araraquara-SP, Brazil
}

\begin{abstract}
RESUMO: "Efeito da descontaminação usando irradiação gama sobre o óleo essencial de Turnera diffusa Wild". Este trabalho descreve a investigação do óleo essencial, obtido das partes aéreas de Turnera diffusa (Turneraceae) submetida a descontaminação usando irradiação com ${ }^{60} \mathrm{Co}$ (raios gama). As analises dos óleos irradiados nos permite verificar diferenças quali e quantitativa nas amostras de óleos.
\end{abstract}

Unitermos: Turnera diffusa, Turneraceae, óleo essencial, descontaminação de plantas, irradiação gama, controle de qualidade.

\begin{abstract}
This paper describes the investigation of the essential oil obtained from the aerial parts of Turnera diffusa Wild. (Turneraceae) submitted to decontamination using irradiation with ${ }^{60} \mathrm{Co}$ (gamma rays). Analyses of the irradiated oils allowed us to verify quali and quantitative differences among the oils.
\end{abstract}

Keywords: Turnera diffusa, Turneraceae, essencial oil, decontamination of plants, gamma irradiation, quality control.

\section{INTRODUCTION}

Turnera diffusa is a plant found in dry and semi-dry regions, which extends from South of USA and Mexico to South America. It is also found in India (Alcaraz-Meléndes et al., 1994). Several biological activities were attributed to T. diffusa (Vieira et al., 1968; Barbosa-Filho et al., 2005; Carlini et al., 2006). Our group has been investigating this species because of its antiulcerogenic properties (Souza Brito \& Souza Brito 1993).

The essential oil of Turnera diffusa has a peculiar scent. Its refraction index is $1.5 \%$ and its density is 0.95 $\mathrm{g} / \mathrm{mL}$. Alonso (1998) reported their expectorant and psycho stimulant activities and suggested that there is a synergism between the oil, damianina and cyanogenic compounds.

Because of its alleged stimulant and aphrodisiac properties, it is commonly found in the commerce as capsules or gum (Weniger et al., 1986).

After collecting, drying and storing, the vegetable material might be contaminated with a large number of microorganisms, which are able to cause physical or chemical changes in the drug or in their metabolites. For this reason, it is necessary to decontaminate the drug.

Previously, usual methods for plants decontamination used sodium hypochlorite or ethylene oxide solutions, but the plants remained contaminated by residues of these substances. More recently, a method accepted by the Brazilian legislation uses gamma radiation to decontaminate foods and products of vegetal origin (Hutzler,1984c; Peregrino \& Leitão, 2005).

Radioisotopes, chemical elements that have the inherent property to emit radiation, emit gamma radiation. The most usual radioisotope in industrial applications is cobalt $\left({ }^{60} \mathrm{Co}\right)$, which is obtained from ${ }^{59} \mathrm{Co}$ (natural isotope) bombardment with neutrons in a nuclear reactor. Each ${ }^{60} \mathrm{Co}$ disintegration causes an emission of one beta particle and two photons with energy of $1.17 \mathrm{MeV}$, originating ${ }^{60} \mathrm{Ni}$, a stable element. As all radioisotopes, the activity of ${ }^{60} \mathrm{Co}$ is reduced in time according to an exponential law, its half-life being 5.3 years (Hutzler, 1984a.)

The raw materials and/or final products are exposed to the radiation in a place specially designed, where they are submitted to a controlled radiation flow and received the pre-established dose of energy. The only parameter to be controlled is the time of exposure. The process does not leave any residues and does not cause temperature rising. As an additional advantage, the irradiated material does not become radioactive and can be handled without any risk (Hutzler, 1984c).

There are few studies about the effect of gamma radiation on products of vegetal origin. Irradiation of the 
sunflower and olive oils at doses of $10 \mathrm{kGy}$ induced the formation of small amounts of $\mathrm{H}_{2} \mathrm{O}_{2}$, without any other detectable change (Hutzler, 1984b). Irradiation of the mint essential oil did not produce significant changes in the monoterpene content (Hutzler, 1999).

\section{MATERIAL AND METHODS}

\section{Plant irradiation}

Five samples of dried and crushed leaves of Turnera diffusa (250 g each) were packed into plastic bags. Four samples were separately irradiated with ${ }^{60} \mathrm{Co}$ with doses of gamma radiation of 5, 10, 15 e $20 \mathrm{kGy}$ at the Embrarrad Company, São Paulo, SP, Brazil. The remaining sample was not radiated (control sample). There was no microbiological analysis of all samples because the purpose of this study was to evaluate the gamma irradiation effect.

\section{Extraction of the essential oil}

The essential oil of the five samples of Turnera diffusa $(250 \mathrm{~g})$ were separatedly extracted with a Clevenger apparatus (1L water) and light protected for 3 hours. The collected oil was dried over anhydrous $\mathrm{Na}_{2} \mathrm{SO}_{4}$ and refrigerated at $4{ }^{\circ} \mathrm{C}$. In sequence, the essential oils obtained were analyzed by GC-FID.

\section{Analyses of the essential oils}

Chromatographic analyses of the essential oil of Turnera diffusa were performed in a Varian CP-3800 chromatograph equipped with flame ionization detector (FID), a Silica SPB-5 capillary column (30 m x $0.25 \mathrm{~mm}$ i.d. $\mathrm{x} 0.25 \mu \mathrm{m}$ ) and a Chrompack automatic injector - a varian 8200 auto sampler. Results were processed with a Varian GW08-V509 workstation registered in mVoltz. Quantifications were performed using cineol and thymol as markers, using the external standard method.

Conditions: injector temperature: $230{ }^{\circ} \mathrm{C}$; detector temperature: $290{ }^{\circ} \mathrm{C}$; column temperature: initial $50{ }^{\circ} \mathrm{C}$, final $280{ }^{\circ} \mathrm{C}$ (holding time 20 minutes); slope ramp: the temperature increased $3{ }^{\circ} \mathrm{C} /$ minute to the final temperature; split ratio: 1:30; carrier gas $\left(\mathrm{H}_{2}\right)$ : $10 \mathrm{psi}\left(1.2 \mathrm{~mL} /\right.$ minute); gas detector $\left(\mathrm{H}_{2}\right): 30 \mathrm{ml} /$ minute; synthetic air: $300 \mathrm{ml} /$ minute; auxiliary gas $\left(\mathrm{N}_{2}\right): 1.5 \mathrm{ml} /$ minute; injected volume: $1 \mu \mathrm{L}$.

Essential oil sample concentration was prepared with $0.66 ; 2.0$ and $6.0 \mu \mathrm{l}$ and dissolved in $1 \mathrm{ml}$ with hexane. The calibration slope was prepared following the United States Pharmacopoeia (USP) standard with $2.0,4.0,6.0,8.0$ and $10 \mathrm{mg} / \mathrm{mL}$ concentration in $10 \mathrm{ml}$ of hexane, respectively.

\section{RESULTS AND DISCUSSION}

The essential oil of Turnera diffusa was submitted to GC-FID analysis showing about 50 peaks, which were separated in 40 minutes. Peaks with retention time between 28.9 and 40 minutes appeared superposed, but those with retention time between 5.0 and 27.8 minutes presented good chromatographic resolution. Therefore, we chose the monoterpenes cineol $\left(\mathrm{R}_{\mathrm{T}}=5.201\right.$ minutes) and thymol $\left(\mathrm{R}_{\mathrm{T}}=14.293\right.$ minutes) (previously identified by their MS spectra and by comparison with authentic standards) to evaluate the possible changes caused by the irradiation of Turnera diffusa with gamma irradiation. After, the chromatography conditions for the cineol and thymol analyses were established we proceeded to the analyses of the oils obtained from the irradiated plants.

Results demonstrated that gamma irradiation led to an irregular change in the cineol and thymol contents (Figures 1 and 2) chemical composition when submitted to the plant decontamination by gamma radiation. This fact indicates that a further study should be carried out in order to evaluate qualitative and quantitatively changes

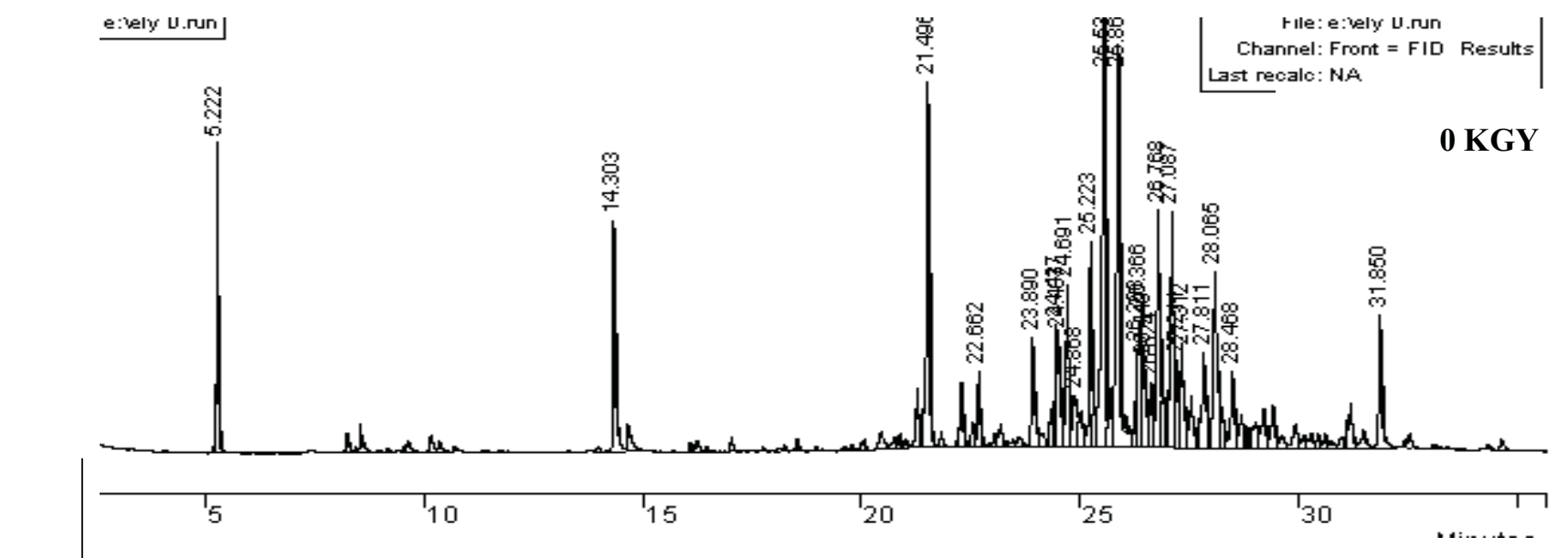

Figure 1. GC/FID Chromatogram from essential oil of Turnera diffusa not irradiationed. 

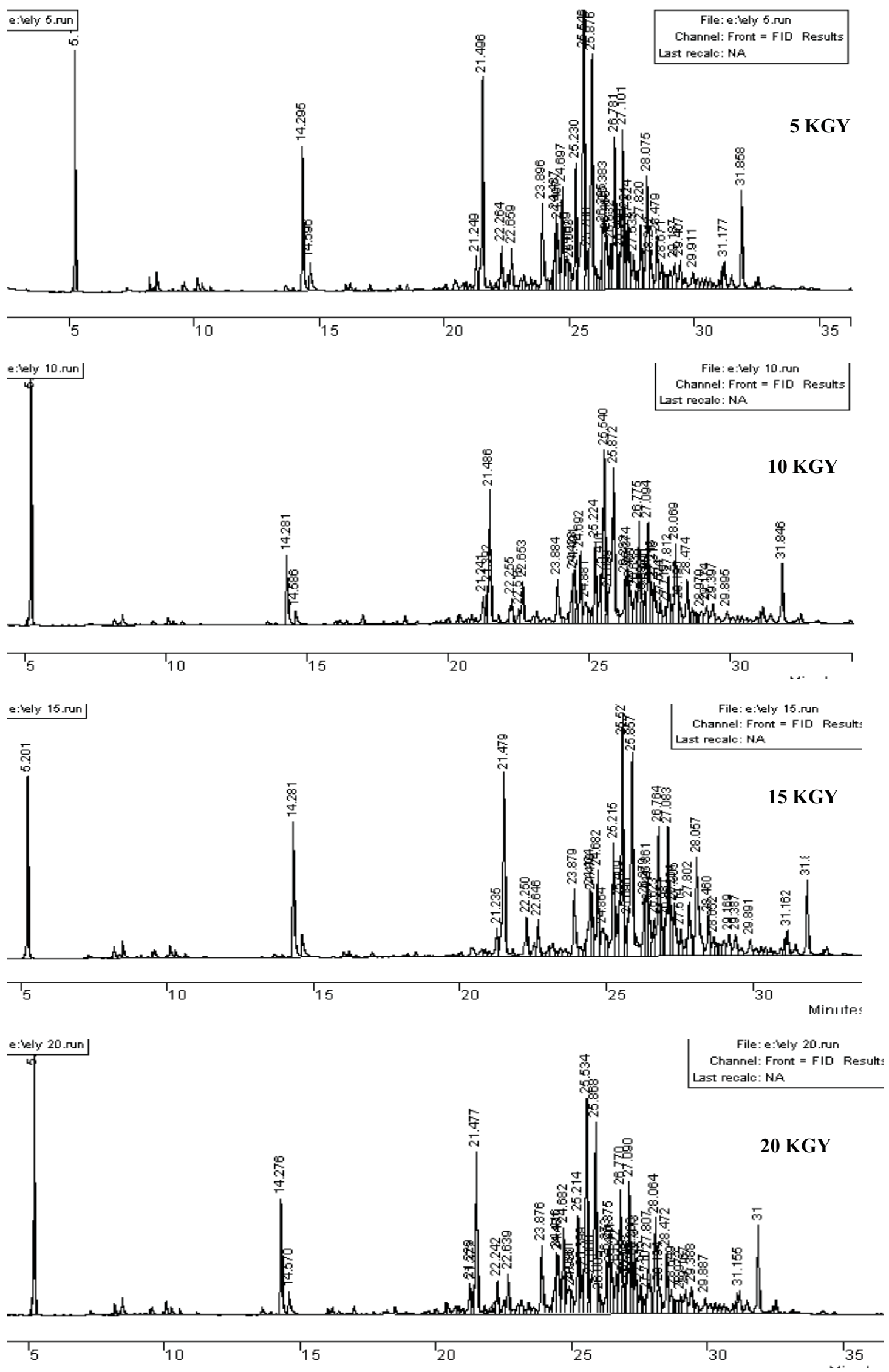

Figure 2. GC/FID Chromatograms from essential oil of Turnera diffusa irradiated with ${ }^{60} \mathrm{Co}$ with doses of gamma radiation of: (A) $5 \mathrm{kGy}$, (B) $10 \mathrm{kGy}$, (C) $15 \mathrm{kGy}$ and (D) $20 \mathrm{kGy}$. 
as well as their biological properties in other medicinal plants.

\section{CONCLUSIONS}

Turnera diffusa essential oil suffers qualitative and quantitative changes when the plant is submitted to the decontamination by gamma radiation, leading to a decrease in the cineol and thymol contents. Therefore, other commercialized medicinal plants that are also submitted to gamma irradiation should be evaluated relatively to their chemical composition and biological properties.

\section{REFERENCES}

Alcaraz-Meléndez L, Real-Cosío S, Bashan Y 1994. Domestication of micropropagated plants of the spice damiana (Turnera diffusa), Plant Cell Rep 13: 679-682.

Alonso J.R 1998. Tratado de fitomedicina - Bases clinicas y farmacológicas. Isis Ediciones S.R.L., Buenos Aires, $1039 \mathrm{p}$.

Barbosa-Filho JM, Vasconcelos THC, Alencar AA, Batista LM, Oliveira RAG, Guedes DN, Falcão HS, Moura MD, Diniz MFFM, Modesto-Filho J 2005. Plants and their active constituents from South, Central, and North America with hypoglycemic activity. Rev Bras Farmacogn 15: 392-413.

Carlini EA, Rodrigues E, Mendes FR, Tabach R, Gianfratti B 2006. Treatment of drug dependence with Brazilian herbal medicines. Rev Bras Farmacogn 16: 690695.

Hutzler R 1984a. Embrarrad - Empresa Brasileira de Radiações S.A $n^{\circ} 16$, São Paulo. Boletim informativo.

Hutzler R 1984b. Embrarrad - Empresa Brasileira de Radiações S.A n ${ }^{\circ} 7$, São Paulo. Boletim informativo b.

Hutzler R 1984c. Embrarrad - Empresa Brasileira de Radiações S.A $n^{\circ} 11$, São Paulo. Boletim informativo.

Hutzler R 1999. Embrarrad - Empresa Brasileira de Radiações S.A Especial, São Paulo. Boletim informativo.

Peregrino CAF, Leitão SG 2005. Chromatographical profi les of fl uid extracts and tinctures obtained from Mikania glomerata Sprengel sterilized by gamma ray irradiation. Rev Bras Farmacogn 15: 237-242.

Souza Brito ARM, Souza Brito A 1993. Forty years of Brazilian medicinal plant research. J Ethnophamacol 39: 53-67.

Vieira JEV, Barros GSG, Medeiros MC, Matos FJA, Souza MP, Medeiros MJ 1968. Pharmacological screening of plant from Northeast of Brazil. Rev Bras Farm 49: 67-75.

Weniger B, Rouzier M, Daguilh R, Henrys D, Henrys JH, Anton T 1986. Popular medicine of the Central Plateau of Haiti 2. Ethnopharmacological inventory. J Ethnopharmacol 17: 13-30. 